\title{
The Impact of Ownership Type and Institutional Environment on Innovation Performance Based on CDM Model
}

\author{
Qian Fang \\ School of Economics \\ Shanghai University \\ Shanghai, China
}

\begin{abstract}
This document adopts a panel data of 45531 stateowned and non-state-owned indus trial enterprises over the scale from 2005 to 2007 and the recursive CDM (structure) model, panel Probit model and consistent estimation to study the effects of ownership types on innovation input, innovation output and TFP enterprise performance, It also analyzes the moderating effect of institutional environment on innovation performance of different ownership enterprises. The studies show that: (1) Compared with other ownership enterprises, state-owned enterprises have more innovation input and stronger innovation output capacity, but their innovation efficiency is not as good as that of private enterprises; (2) Ins titutional environment not only significantly affects $R \& D$ input behavior $(R \& D$ input persis tence and $R \& D$ input intensity), but also through innovative production. And then affect enterprise performance. The empirical results have important practical significance for the transformation of enterprise ownership structure, the improvement of institutional environment, and the study of how to improve enterprise innovation performance.
\end{abstract}

Keywords-Ownership Type; Innovation Performance; Institutional Environment; CDM Model

\section{INTRODUCTION}

In order to improve the productivity of enterprises and maintain sustained growth, China has invested tremendous resources in improving the innovation capability of enterprises [1]. In order to improve the innovation ability of enterprises and obtain higher added value, China has given enterprises comprehensive support, whether from industrial policy or financial support. Opening more policies and markets to private enterprises is conducive to the reform of socialist market economy and the enhancement of market vitality. Of course, due to macro-control and economic security factors, state-owned capital must also play a leading role in important areas related to national security and national economy [2]. Therefore, it is of great significance to explore the role of stateowned enterprises and private enterprises in the marketoriented reform from the perspective of innovation.

Corporate performance is influenced by governance structure, and governance structure is based on enterprise ownership. Therefore, what type of enterprise ownership can promote the innovation capability of enterprises? In recent years, this problem has become one of the key issues in academic circles both at home and abroad [3].

At the same time, China is still in the period of economic transition, the institutional environment in different regions is still quite different, not only in the intellectual property protection system gap, but also in the degree of marketization gap. Therefore, under the institutional environment of different regions, it is worth exploring how the nature of ownership affects enterprise innovation in China.

\section{CALCULATION METHOD}

\section{A. CDM model}

In order to study the relationship between ownership and enterprise innovation in an all-round way, we construct a CDM recursive equation model which consists of three functional equations of innovation input, innovation output and enterprise efficiency. CDM recursive structure equation is composed of three stages and four recursive equations: (1) Decision-making of R\&D investment; (2) Investment equation of R\&D when enterprises decide to invest in R\&D; (3) Knowledge (innovation) function, R\&D as input into the function; (4) Production function, knowledge (innovation) as an explanatory variable into the function.

\section{1) Innovation behavior model}

There are many factors that affect corporate innovation behavior. Referring to previous studies, we set the following models for innovative behavior:

$$
\begin{aligned}
R \& D_{i j k t}= & \beta_{0}^{(1)}+\beta_{1}^{(1)} \operatorname{LnTFP}_{i j k t}+\beta_{2}^{(1)} \text { Soe }_{i j k t}+\beta_{3}^{(1)} \text { Mar }_{k t} \\
& +\beta_{4}^{(1)} \text { Fin }_{k t}+\beta_{5}^{(1)} \text { Law }_{k t}+\lambda_{1}^{(1)} \text { Ins } * \text { SOE }+\varepsilon_{i j k t}^{(1)}
\end{aligned}
$$

Where $\varepsilon_{i j k t}$ is random perturbation term. I, j, k, t represents enterprises, industries, provinces and years respectively. $R \& D_{i j k t}$ is enterprise investment activities, there are two kinds of situations: dummy variables and quantitative variables. The R\&D input is set to 1 , the $R \& D$ input is set to 0 , and the quantitative variable indicates the intensity of the enterprise's innovation input. This paper uses the number of R\&D input / the natural logarithm of the number of employees to measure 
the intensity of innovation input. $\operatorname{LnTFP}_{i j k t}$ is the natural logarithm of enterprise efficiency, SOE is ownership type. The background of environmental system consists of Fan Gang et al. (2011) degree of marketization (Mar), financial environment (Fin), legal environment (Law). Ins*SOE is the interaction between institutional background and ownership type, and other regulates the role of main explanatory variables. Other controlling variables are: Age, Size, Sub, Liqu, Cap, Roe, Lev, and Sal.

\section{2) Innovation output function equation}

The second equation is the innovation output function equation, which mainly studies the relationship between innovation input and innovation output and its influencing factors. The empirical models are as follows:

$$
\begin{aligned}
N p s_{i j k t} & =\beta_{0}^{(2)}+\beta_{1}^{(2)} R d_{i j k t}+\beta_{2}^{(2)} \text { Soe }_{i j k t}+\beta_{3}^{(2)} \operatorname{Mar}_{k t} \\
& +\beta_{4}^{(2)} \text { Fin }_{k t}+\beta_{5}^{(2)} L a w_{k t}+\lambda_{1}^{(2)} I n s * S O E+\varepsilon_{i j k t}^{(2)}
\end{aligned}
$$

Model 2 is a model of technological innovation output. The explained variable is the natural logarithm of new product output value (Nps). In addition to the firm characteristics (ownership type, age, size, etc.) and institutional background (Ins) in model $1, \mathrm{R} \& \mathrm{D}$ input $(\mathrm{Rd} *$ ) also affects innovation output.

\section{3) Production function equation}

The last equation is the production function equation, which is as follows:

$$
\begin{aligned}
\operatorname{LnTFP}_{i j k t} & =\beta_{0}^{(3)}+\beta_{1}^{(3)} N p s_{i j k t}+\beta_{2}^{(3)} \operatorname{SOE}_{i j k t}+\beta_{3}^{(3)} \operatorname{Mar}_{k t} \\
& +\beta_{4}^{(3)} \operatorname{Fin}_{k t}+\beta_{5}^{(3)} L a w_{k t}+\lambda_{1}^{(3)} \text { Ins } * S O E+\varepsilon_{i j k t}^{(3)}
\end{aligned}
$$

In the enterprise performance model of model 3 , the explanatory variable is enterprise performance LnTFP, which is measured by the logarithm of total factor productivity (TFP) of the year, and is constructed by Olley (1996) method.

\section{B. TFP measurement method}

Enterprise productivity refers to the efficiency of getting the maximum output under the input of the enterprise unit. Generally, labor productivity and total factor productivity are used to measure enterprise productivity. By adopting the method of Olley and Pakes (1996), we get the total factor productivity TFP of enterprises:

$$
T F P_{i t}^{O P}=\exp \left(y_{i t}-\beta_{m} m_{i t}-\beta_{k} k_{i t}\right)
$$

\section{EVALUATION RESULTS}

\section{A. Data}

We used the database of all state-owned and Non-stateowned Industrial Enterprises above the scale from 2005 to 2007, and cleaned up the data of 45531 enterprises. We use this data because it is a good representation of China's economy during this period. These data include state-owned and nonstate-owned enterprises with revenues of more than 5 million, accounting for $95 \%$ of China's total industrial output during this period.
Each enterprise sample includes more than 100 indicators such as new product sales, R\&D input, total output, main business income, etc. The data also contains a very detailed classification of industries, including a total of the national economy four classifications.

\section{B. Results}

From the point of view of the actual value of innovation, the whole process of technological innovation should include two stages: the first stage from R\&D input to innovation output, and the second stage from commercialization of innovation achievements. Therefore, this paper focuses on whether the differences of ownership types affect the innovation behavior of enterprises, and how the innovation behavior affects the performance of enterprises.

Our basic empirical results are as follows: Table III and Table IV, Table III is the empirical results based on stateowned enterprises, Table IV is the empirical results based on private enterprises, we mainly use $\mathrm{R}$ language for empirical analysis.

1) The influence of ownership on enterprise innovation activities

SOE in the model (1-1) and POE in the model (1-2) coefficients were 0.2352 and 0.1132 , respectively. On the surface, compared with private enterprises, state-owned enterprises pursue innovation investment more sustainable, and R\&D investment is significantly higher than private enterprises; at the same time, POE in the model (2-1) and model (2-2) coefficients are significant. The results show that compared with state-owned enterprises, private enterprises' innovation input is negative, and private enterprises' $\mathrm{R} \& \mathrm{D}$ input is not sustainable, which benefits more from imitation innovation.

The Marketization Degree Index (Mar) is negative in the model (1-1) and positive in the model (1-2), (2-1), (2-2). It shows that the higher the degree of marketization is, the more negative the sustainability of $R \& D$ is, and the higher the degree of marketization is for private enterprises. The higher the degree of marketization, the higher the sustainability of $R \& D$ investment and the intensity of innovation. Financial environment (Fin) has positive coefficients in model (1-1) and model (1-2), negative coefficients in model (2-1) and model (2$2)$, negative coefficients in model (2-1) and legal environment (2-2), and negative coefficients in model (1-1) and model (1-2) for interactive terms Fin * SOE and Law * SOE, and negative coefficients in model (2-1) and model (1-2) for interactive terms Fin * SOE and Law * SOE. (2-2) Neutral is positive and significant, which indicates that the legal and financial environment weakens the sustainability and intensity of innovation input of state-owned enterprises, but strengthens the innovation input of private enterprises.

2) The impact of ownership on innovative output of enterprises

We use the panel random effect model to obtain the basic empirical results of the impact of ownership on innovation output, such as table III (1-3) and table IV (2-3). Among them, we can see from the table: 
The influence of explanatory variables on enterprise innovation. The coefficient of SOE is significantly negative and the coefficient of POE is positive, which indicates that the efficiency of SOE is insufficient and the private enterprises have stronger efficiency [5]. In addition, the coefficients of innovation input persistence $(\mathrm{RD} *)$ and innovation input intensity $(\mathrm{RDI} *)$ are significantly positive, indicating that R\&D input has a significant role in promoting the efficiency of innovation output in the process of innovation, which also shows that R\&D input factors play a fundamental role in innovation output.

In terms of institutional environment, the coefficients of Mar and Law are significantly positive in the model (1-3) and model (2-3), and the coefficients of interactive terms Mar*SOE, Law*SOE, Mar*POE and Mar*POE are all positive, which shows that institutional background has a positive impact on enterprise innovation, and institutional environment is also positive. It has strengthened the ability of innovation and creation of enterprises.

3) The impact of ownership type on innovation performance

The coefficient of SOE is negative and the coefficient of POE is positive, which indicates that private enterprises have more ability to transform innovation capability into enterprise performance than state-owned enterprises in the process of innovation. This may be that private enterprises with profitmaking purpose have more incentive to commercialize innovation achievements than those with enterprises, making private enterprises more competitive than state-owned enterprises. More efficient in the transformation of innovation achievements.

Marketization degree (Mar) is positive in both model (1-4) and model (2-4), and the coefficients of SOE * Mar and POE * Mar are positive, indicating that marketization degree has a positive effect on firm performance; financial environment (Fin) is negative in model (1-4), positive in model (2-4), and SOE * Fin is positive in model (2-4). The coefficients are all positive, and the financial environment can restrain the performance of state-owned enterprises, but the nature of state-owned property rights weakens the effect.

TABLE I. EFFECT OF OWNERSHIP TYPE ON ENTERPRISE INNOVATION PERFORMANCE (BASED ON ST ATE-OWNED ENTERPRISES)

\begin{tabular}{|c|c|c|c|c|}
\hline & \multicolumn{2}{|c|}{ Innovative behavior } & \multirow[b]{2}{*}{$\begin{array}{c}\text { Innovation } \\
\text { output } \\
\text { (RE) } \\
(1-3)\end{array}$} & \multirow[b]{2}{*}{$\begin{array}{c}\text { Enterprise } \\
\text { efficiency } \\
\text { (OLS) } \\
(1-4)\end{array}$} \\
\hline & $\begin{array}{c}\text { Innovation } \\
\text { decision } \\
\text { ( RE } \\
\text { Probit) } \\
(1-1)\end{array}$ & $\begin{array}{c}\text { Innovation } \\
\text { inves tment } \\
\text { (uniform } \\
\text { estimate) } \\
(1-2)\end{array}$ & & \\
\hline $\mathrm{RD}^{*}$ & & & $\begin{array}{l}0.2803^{*} \\
(0.1345) \\
\end{array}$ & \\
\hline RDI* & & & $\begin{array}{c}0.1325^{* * *} * \\
(0.0111)\end{array}$ & \\
\hline NPs* & & & & $\begin{array}{c}0.1242 * * * \\
(0.0231)\end{array}$ \\
\hline TFP & $\begin{array}{c}0.1538 * * * \\
(0.0059)\end{array}$ & $\begin{array}{c}-0.0587 \\
(0.1785)\end{array}$ & & \\
\hline SOE & $\begin{array}{c}0.2352 * * \\
(0.0982)\end{array}$ & $\begin{array}{c}0.1132 \\
(0.1442)\end{array}$ & $\begin{array}{l}-0.5297 \\
(0.3777)\end{array}$ & $\begin{array}{l}-0.8509 * * * \\
(0.2376)\end{array}$ \\
\hline Mar & $\begin{array}{l}-0.0096 \\
(0.0071) \\
\end{array}$ & $\begin{array}{c}0.1988 * * * \\
(0.0418)\end{array}$ & $\begin{array}{l}0.0408^{*} \\
(0.0265) \\
\end{array}$ & $\begin{array}{l}-0.0382^{* *} \\
(0.0158)\end{array}$ \\
\hline
\end{tabular}

\begin{tabular}{|c|c|c|l|l|}
\hline \multicolumn{5}{|c|}{ Cont. to TABLE I } \\
\hline \multirow{2}{*}{ Fin } & $\begin{array}{c}0.0262^{* * *} \\
(0.0045)\end{array}$ & $\begin{array}{c}0.0011 \\
(0.0139)\end{array}$ & $\begin{array}{l}-0.0217 \\
(0.0173)\end{array}$ & $\begin{array}{l}-0.0151 \\
(0.0112)\end{array}$ \\
\hline & $-0.0226^{* * *}$ & $-0.0563^{* *}$ & $0.0713^{* * *}$ & $0.0222^{* *}$ \\
Law & $(0.0055)$ & $(0.0228)$ & $(0.0204)$ & $(0.0119)$ \\
\hline & $0.0477^{* *}$ & $0.0535^{* *}$ & $0.1224^{*}$ & 0.0054 \\
Mar*SOE & $(0.0177)$ & $(0.0248)$ & $(0.0669)$ & $(0.0405)$ \\
\hline & $-0.0572^{* * *}$ & $-0.0475^{* * *}$ & $-0.0739^{*}$ & $0.0707^{* *}$ \\
Fin*SOE & $(0.0123)$ & $(0.0176)$ & $(0.0448)$ & $(0.0336)$ \\
\hline & $-0.0211^{*}$ & $-0.0474^{* * *}$ & 0.0162 & -0.0033 \\
Law*SOE & $(0.0126)$ & $(0.0179)$ & $(0.0527)$ & $(0.029)$ \\
\hline R-squared & & 0.2256 & 0.32656 & 0.1488 \\
\hline F value & & 126.784 & 242.057 & 42.4 \\
\hline Sample & & & & \\
number & 136593 & 136593 & 91062 & 45531 \\
\hline
\end{tabular}

TABLE II. THE INFLUENCE OF OWNERSHIP TYPE ON ENTERPRISE INNOVATION PERFORMANCE BASED ON PRIVATE ENTERPRISES

\begin{tabular}{|c|c|c|c|c|}
\hline & \multicolumn{2}{|c|}{ Innovative behavior } & \multirow[b]{2}{*}{$\begin{array}{c}\text { Innovation } \\
\text { output } \\
\text { ( RE) } \\
(2-3)\end{array}$} & \multirow[b]{2}{*}{$\begin{array}{c}\text { Enterprise } \\
\text { efficiency } \\
\text { (OLS) } \\
(2-4)\end{array}$} \\
\hline & $\begin{array}{c}\text { Innovation } \\
\text { decision } \\
\text { ( RE } \\
\text { Probit) } \\
(2-1)\end{array}$ & $\begin{array}{c}\text { Innovation } \\
\text { investment } \\
\text { (uniform } \\
\text { estimate) } \\
(2-2)\end{array}$ & & \\
\hline $\mathrm{RD}$ & & & $\begin{array}{l}0.1809^{*} \\
(0.1345) \\
\end{array}$ & \\
\hline RDI & & & $\begin{array}{l}0.1125^{* * *} \\
(0.0111) \\
\end{array}$ & \\
\hline NPs & & & & $\begin{array}{l}0.1242^{* * *} \\
(0.0231)\end{array}$ \\
\hline TFP & $\begin{array}{l}0.1538 * * * \\
(0.0059) \\
\end{array}$ & $\begin{array}{l}0.2305^{* * * *} \\
(0.0079) \\
\end{array}$ & & \\
\hline POE & $\begin{array}{l}-0.2352 * * \\
(0.0982) \\
\end{array}$ & $\begin{array}{l}-0.1132 \\
(0.1442) \\
\end{array}$ & $\begin{array}{l}0.5297 \\
(0.3777)\end{array}$ & $\begin{array}{l}0.8509 * * * \\
(0.2376)\end{array}$ \\
\hline Mar & $\begin{array}{l}0.0382 * * \\
(0.0165)\end{array}$ & $\begin{array}{l}0.2523 * * * \\
(0.0477) \\
\end{array}$ & $\begin{array}{l}0.1632 * * * \\
(0.0617) \\
\end{array}$ & $\begin{array}{l}-0.0327 \\
(0.0374) \\
\end{array}$ \\
\hline Fin & $\begin{array}{l}-0.031 * * * \\
(0.0115) \\
\end{array}$ & $\begin{array}{l}-0.0464^{* *} \\
(0.021)\end{array}$ & $\begin{array}{l}-0.0956^{* *} \\
(0.0418)\end{array}$ & $\begin{array}{l}0.0556^{*} \\
(0.0319) \\
\end{array}$ \\
\hline Law & $\begin{array}{l}-0.0437 * * * \\
(0.0118)\end{array}$ & $\begin{array}{l}-0.1037 * * * \\
(0.0268) \\
\end{array}$ & $\begin{array}{l}0.0875^{*} \\
(0.0486) \\
\end{array}$ & $\begin{array}{l}0.0189 \\
(0.0268) \\
\end{array}$ \\
\hline Mar*POE & $\begin{array}{l}-0.0477 * * * \\
(0.0177)\end{array}$ & $\begin{array}{l}-0.0535^{* *} \\
(0.0248)\end{array}$ & $\begin{array}{l}0.1424^{*} \\
(0.0669) \\
\end{array}$ & $\begin{array}{l}0.0063 \\
(0.0405) \\
\end{array}$ \\
\hline Fin*POE & $\begin{array}{l}0.0572^{* * *} \\
(0.0123) \\
\end{array}$ & $\begin{array}{l}0.0475^{* * *} \\
(0.0176) \\
\end{array}$ & $\begin{array}{l}0.0739 * \\
(0.0448) \\
\end{array}$ & $\begin{array}{l}0.0033 \\
(0.029) \\
\end{array}$ \\
\hline $\mathrm{Law}^{*} \mathrm{POE}$ & $\begin{array}{l}0.0211^{*} \\
(0.0126) \\
\end{array}$ & $\begin{array}{l}0.0474 * * * \\
(0.0179) \\
\end{array}$ & $\begin{array}{l}0.0172 \\
(0.0527) \\
\end{array}$ & $\begin{array}{l}-0.0707^{* *} \\
(0.0336) \\
\end{array}$ \\
\hline R-squared & & 0.2257 & 0.3266 & 0.1488 \\
\hline F value & & 126.78 & 242.06 & 42.4 \\
\hline $\begin{array}{l}\text { Sample } \\
\text { number }\end{array}$ & 136593 & 136593 & 91062 & 45531 \\
\hline
\end{tabular}

\section{CONCLUSION}

This document studies the types of ownership, the innovation input of institutional environment, the innovation output and the enterprise performance comprehensively by using large sample of enterprise micro-data and CDM model, and puts forward a new perspective for the study of the performance problems and their influencing factors of ownership enterprises.

Based on the panel data of Industrial Enterprises above the national scale from 2005 to 2007, this paper constructs a CDM analysis framework consisting of innovation input model, innovation function model and production function. The panel Probit model, consistent estimation and OLS model are used to test the innovation input, innovation output and enterprise performance of different ownership enterprises. The influence 
of ownership type enterprises on the innovation efficiency of enterprises under the institutional background is studied in depth. We found:

(1) Compared with private enterprises, state-owned enterprises' R\&D input intensity is more, and $R$ \& $D$ investment is more sustainable. The R\&D input intensity and sustainability of enterprises are positively related to the size of enterprises and the number of years of establishment. At the same time, the more perfect the institutional environment, state-owned enterprises and private enterprises $R \& D$ investment are inclined to more $\mathrm{R} \& \mathrm{D}$ investment, but private enterprises property rights weakening this effect.

(2) The innovation output of private enterprises is lower than that of state-owned enterprises, but the efficiency of innovation output is higher than that of state-owned enterprises. From the current situation in China, state-owned enterprises have to grasp more innovative resources. For the manufacturing industry, R\&D innovation needs a wealth of capital input, and innovation also needs to be sustained in order to have a significant effect. Private enterprises are far less advantageous than state-owned enterprises. In addition, the scale of enterprises and the output of enterprises' innovation also have a positive effect. At present, the scale of state-owned enterprises is much larger than that of private enterprises, so the capacity of innovation and output of state-owned enterprises is stronger, but the per capita sales volume and per capita profit of private enterprises for profit-making purposes are significantly higher than that of the state. Enterprises, i.e. private enterprises, are more efficient in terms of innovation output than state-owned enterprises.

(3) The ability of private enterprises to transform their innovative achievements into commercial value is stronger than that of state-owned enterprises. At the same time, by observing the regulatory effect of different institutional backgrounds on enterprise innovation efficiency, we find that both state-owned enterprises and private enterprises, the degree of marketization and legal environment have a very good role in promoting enterprise performance. Financial environment has a restraining effect on enterprise performance of stateowned enterprises, but a positive effect on private enterprises.

The conclusion of this paper has important policy implications. Firstly, we should establish the mechanism and policy measures to guarantee the development of innovation, solve the deep-seated problems that restrict innovation, and urge the main market innovators to innovate in the environment of fair competition, so as to protect the innovative achievements of economic entities. Perfect the system and the legal policy system, especially the investment policy, the industrial policy, the innovation incentive mechanism and so on, to form the fair competition market environment. Intellectual property rights protection should be strengthened, innovation transformation mechanism should be handled properly, market demand oriented innovation should be guided and grass-roots knowledge research and development oriented innovation should be combined, so that the mechanism of industry, University and research can play a greater role.

\section{REFERENCES}

[1] Liu F C, Simon D F, Sun Y T, et al. China's innovation policies: Evolution, institutional structure, and trajectory[J]. Research Policy, 2011, 40(7):917-931.

[2] Currie J. Research on Productivity Growth and Productivity Differences: Dead Ends and New Departures[J]. Journal of Economic Literature, 2010, 29(19):1029-64.

[3] Choi S B, Lee S H, Williams C. Ownership and firm innovation in a transition economy: Evidence from China[J]. Research Policy, 2011, 40(3):441-452.

[4] Nie H H, Jiang T, Yang R D. Application status and potential problems of China's industrial enterprise database [J]. World economy, 2012(5):142-158. (In Chinese)

[5] Wu Y B. What kind of ownership type enterprise is the most innovative in China? [J]. world economy, 2012(6):3-29. (In Chinese)

[6] Liu H W, Zheng S L, Wang Y F. Ownership type, technological innovation and enterprise performance [J]. Soft science in China, 2015(3):28-40.(In Chinese) 